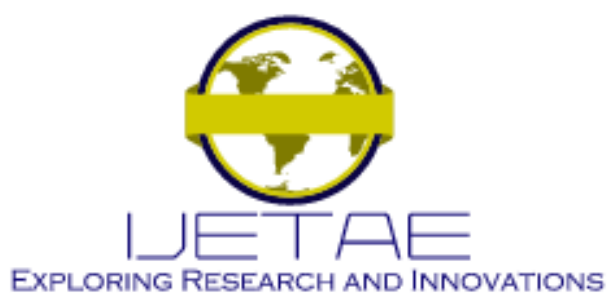

International Journal of Emerging Technology and Advanced Engineering

Website: www.ijetae.com (E-ISSN 2250-2459, Scopus Indexed, ISO 9001:2008 Certified Journal, Volume 12, Issue 02, February 2022)

\title{
Design of a Body Temperature Measurement System applied to Health Center Personnel
}

\author{
Rosa Perez-Siguas ${ }^{1}$, Eduardo Matta-Solis ${ }^{2}$, Hernan Matta-Solis ${ }^{3}$ \\ ${ }^{1,2,3}$ Universidad María Auxiliadora \& Av. Canto Bello 431, San Juan de Lurigancho
}

\begin{abstract}
COVID19 has left a crisis in the economy around the world, being a highly contagious virus and not having adequate control, it spread through many countries, which is why it was declared a pandemic on March $11^{\text {th }}, \mathbf{2 0 2 0}$, by the World Organization of health (WHO). Until the beginning of May 2021, more than 153 million people have been infected and it has caused more than 3.2 million deaths around the world. In Peru, the first case was confirmed on March $6^{\text {th }}, 2020$, with the number of cases rapidly increasing and the first fatalities appearing on March 19 (three on the same day) and two in the following days. With this, COVID19 made us see how in our country the health system was not prepared to face a problem of such magnitude, therefore, naked the terrible health situation in Peru. In view of this problem, in this article the design of a body temperature measurement system applied to the health center staff was carried out, in such a way that it measures the body temperature of each person who enters the health center, with this, we would have greater control and in addition to helping to avoid spreading the virus that currently continues in our environment. Through the design of the system, it was observed that the system worked in the best way by making the personnel in charge aware of the measurements made by the system.
\end{abstract}

Keywords-- Arduino, Buzzer, COVID-19, Sensors, COVID19, WHO, Peru, Proteus.

\section{INTRODUCTION}

COVID-19 has left a crisis in the economy around the world, causing many countries to seek solutions to combat this virus that originated in Wuhan, a city in China, on December 31, 2019 [1] and declared a pandemic on March 11, 2020 by the World Health Organization (WHO) [2] because, being a highly contagious virus, it was not adequately controlled and the virus spread through many countries.

After confirming the first cases in Wuhan, the place where the virus appeared, until the beginning of May 2021, more than 153 million people have been infected and it has caused more than 3.2 million deaths [3] around the world.
Imposing transcendental changes in human dimensions on the world, generating a reality of disease and death in the world population [4], being one of the greatest catastrophes that will be marked in the contemporary history of humanity, because it put everything in difficulty. the health system [5].

COVID-19, being a highly transmissible and pathogenic infection caused by the severe acute respiratory syndrome coronavirus 2 (SARS-COV-2) [6], has reached all countries around the world, so Peru is no stranger to said pandemic, the first case being confirmed on March 6, 2020 [7] and the number of cases rapidly increasing and the first fatalities appearing on March 19 (three on the same day) and two in the following days [8].

From that moment, the lives of many Peruvians have changed, since the government declared some prevention measures to reduce the transmission of SARS-CoV-2, since, at the beginning of 2020, the government did not have policy measures in place. public health to control or eliminate COVID-19, taking into account that it is a new virus, that there is no previous immunity in the general population and that there are no effective and validated vaccines or treatments [9]. Therefore, there was no adequate control to decrease the number of contagions between people.

In the country, COVID-19 made us see how our health system was not prepared to face a problem of this magnitude, thus, naked in a crude and real way the terrible health situation in Peru [10]. For this reason, the government adopted some biosecurity measures so that people do not become infected and thus avoid saturating the health system at the national level. One of these biosafety measures that is used in various public places is taking the temperature with the help of an infrared thermometer, a topic that has generated discussion by many specialists in the area in medicine because this electronic device easily has alterations in the measurement if there is a change from heat to cold on the surface [11]. They consider a normal temperature if it is in the range of $35.1^{\circ} \mathrm{C}$ to $37.1^{\circ} \mathrm{C}$ and a high temperature if it is greater than $37.1^{\circ} \mathrm{C}$ [12]. 


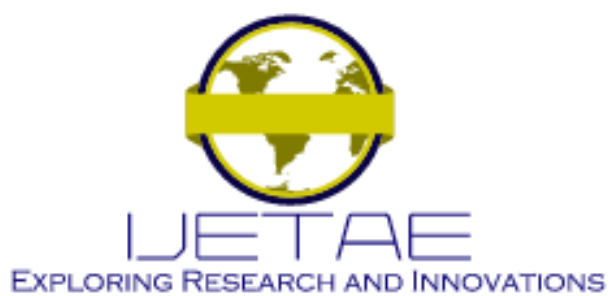

International Journal of Emerging Technology and Advanced Engineering Website: www.ijetae.com (E-ISSN 2250-2459, Scopus Indexed, ISO 9001:2008 Certified Journal, Volume 12, Issue 02, February 2022)

The objective of this research work is to design a body temperature measurement system applied to health center personnel to know if their body temperature is normal or elevated, with this, it will be known if a person has a fever, a common symptom of COVID -19, this will avoid spreading the virus between people. For the elaboration of the system, the person will be analyzed and through the ultrasonic sensor it will be located at a short distance of 50 $\mathrm{cm}$ in front of the body temperature sensor, this, through programming in Arduino IDE. Arduino IDE is a platform that allows us to program any Arduino board, this programming being very friendly that can be easily grasped by any reader with basic programming knowledge.

In section II, a review of some research works that were previously developed was conducted. In section III, the methodology will indicate the flow diagram of the system and the electronic part that makes up the system. In section $\mathrm{IV}$, the detection of body temperature will be indicated. In section $\mathrm{V}$, the simulation of the body temperature detection system will be indicated. In section VI, the results that are generated according to the tests conducted with the system design will be presented. In section VII, the discussion will be presented, where the importance of this work with respect to other works conducted will be indicated. Finally, in section VIII, the conclusion and recommendation obtained from the design of the system will be presented.

\section{LITERATURE REVIEW}

COVID-19 is a virus that cannot be known with the naked eye if a person contains it within their body, therefore, it needs to be evaluated by a specialist to perform the corresponding examination. Therefore, it is necessary to maintain the necessary care to avoid getting the virus, using a system that allows knowing the body temperature of people, if you have an elevated temperature, you may have a fever, a common symptom of COVID-19. For example: In [13], the author identified that COVID-19 affected the wellbeing of the world population, with the elderly being those who present the highest risk of contracting this virus, which has not yet disappeared and continues to affect all people, That is why they proposed to make a temperature and oxygen saturation measurement system for the monitoring of patients diagnosed by COVID-19 and its epidemiological fence, through the use of machine learning algorithms, with the use of IoT applications.
The proposed method consists of using a temperature sensor and an oximeter, using the Blynk application to remotely observe the data by the person in charge of monitoring and the Cayenne application for the patient to view their data using the MQTT communication protocol. Obtaining as a result a measurement efficiency of $96.45 \%$, concluding that its measurement system of these two variables (body temperature and level of oxygen saturation in the blood) in the same structure is more useful.

In [14], the authors identified that COVID-19 has caused economic catastrophes throughout the world, causing economic decline throughout the country, therefore, many countries were forced to resume work activities complying with biosafety standards considering A common symptom of COVID-19, high temperature, is why they proposed to carry out an Implantation of a thermographic device to identify body temperature in means of public transport in the MDQ. The proposed method consists of analyzing a series of data collected between the thermographic device and LyfTrack, revealing that the thermographic device can perform measurements up to 5 individuals with a minimum margin of error as it is located at a height of $1.75 \mathrm{~m}$ with $1 \mathrm{~m}$, with these parameters the error rates are minimal. Obtaining as a result an efficiency of $95.12 \%$ since the thermographic device has variations in relation to the distance and the height that it is located, the ambient temperature and the height of the individual to be measured, concluding that for the measurement it is necessary to use the mentioned values so that the device works accurately and efficiently.

In [15], the authors identified that the measurement of the body temperature of people is essential for clinical research, in people during their physical activities thermoregulation plays an important role in preventing the risks of heat stress and this would affect the people because they would not reach their normal temperature, that is why they proposed to make a Wireless System for the Estimation of Average Body Temperature. The proposed method consists of developing a non-invasive wireless system to measure tympanic temperature and skin temperature, using as a sensor a ZTP-115T thermopile, an LM35 sensor, an HC-05 module, two PIC microcontrollers and used the MATLAB software. for the graphical interface, so that the data is recorded and stored. Obtaining as a result a measurement efficiency of $91.47 \%$, concluding that its system solves the lack of non-invasive systems in medicine. 


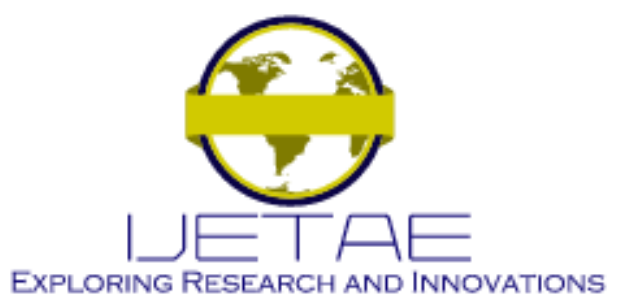

International Journal of Emerging Technology and Advanced Engineering Website: www.ijetae.com (E-ISSN 2250-2459, Scopus Indexed, ISO 9001:2008 Certified Journal, Volume 12, Issue 02, February 2022)

In [16], the authors identified that it is necessary to measure the body temperature of people inside and outside places where there is an agglomeration of people, since the pandemic caused by COVID-19 affected the whole world, infecting many people, making it necessary to carry out selfprotection to prevent contagions, that is why they proposed to design and implement a roll call system with body temperature measurement and instant messaging software. The proposed method consists of using an infrared temperature sensor together with instant messaging software, they will send the collected data to the cloud to later send the body temperature value to a mobile phone. Obtaining as a result an efficiency of $92.84 \%$ of operation, concluding that it is necessary to use the technology specified for the elaboration of the system and thus be able to send information on the person's body temperature to the person in charge.

Finally, in [17], 1 the authors identified that they commonly use an infrared thermometer to measure the body temperature of all the people who enter a shopping center, specifying that these equipment do not measure correctly because these equipment have many errors, that is for this reason, they proposed to develop an automatic recording system for forehead temperature measurement. The proposed method consists of using an infrared sensor, an RFID card to register the user so that they are sent to the database and can be viewed by a computer or an application on the mobile phone. Obtaining as a result an efficiency of $98.5 \%$, concluding that the system is scalable, it adapts easily when there are many people registering, so your system will have a superior performance.

\section{METHODOLOGY}

In this section, the flow chart of the body temperature measurement system for the health center staffs and the electronic part that is part of the system will be made. This flow chart describes how the system works so that you can measure body temperature and see if you have a fever, a common symptom of COVID-19.

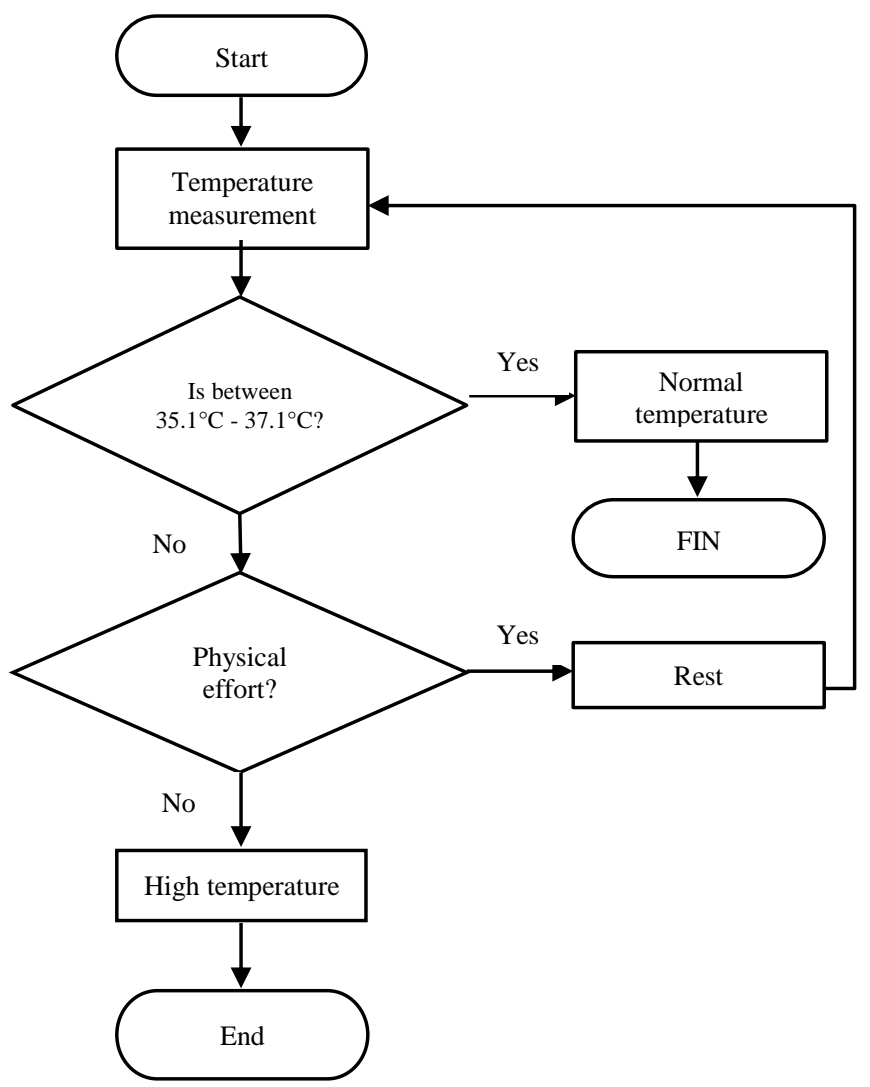

Next, the most important electronic components that are part of the body temperature measurement system will be specified.

\section{A. Arduino UNO}

With the Arduino UNO board, as shown in figure 1, the programming was carried out so that the system works automatically, this being the one in charge of receiving the data that are sent by the sensors or modules and performing a certain function according to what is indicated in its programming [18]. 


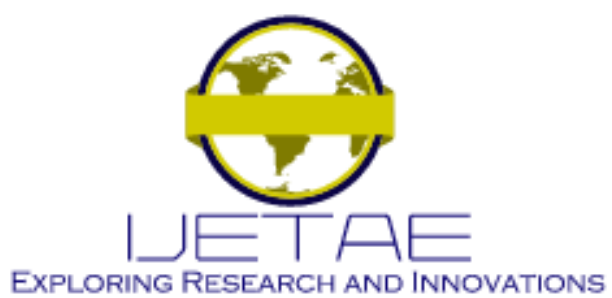

International Journal of Emerging Technology and Advanced Engineering Website: www.ijetae.com (E-ISSN 2250-2459, Scopus Indexed, ISO 9001:2008 Certified Journal, Volume 12, Issue 02, February 2022)

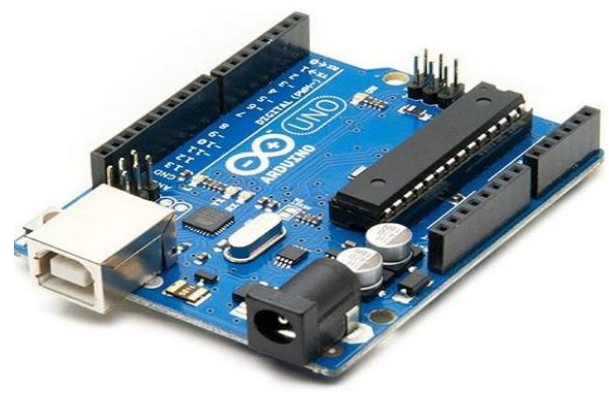

Fig. 1. Arduino UNO

The Arduino UNO was used because it has a free platform to program, facilitating its programming since it has many libraries, and the Arduino UNO board is less expensive than other boards. In addition, for its programming it has its own platform called Arduino IDE, being especially useful so that any user can conduct the programming of a certain project.

\section{B. Ultrasonic Sensor HC-SR04}

With the ultrasonic sensor, as seen in figure 2, we will calculate the distance the person should be in front of the system. With this, it would facilitate the person in charge of the system, showing the value of the distance in which the person is located; The HC-SR04 ultrasonic sensor was used because it is a low cost sensor and also works in a range of 2 $\mathrm{cm}-450 \mathrm{~cm}$ [19], so this sensor is useful for the system.

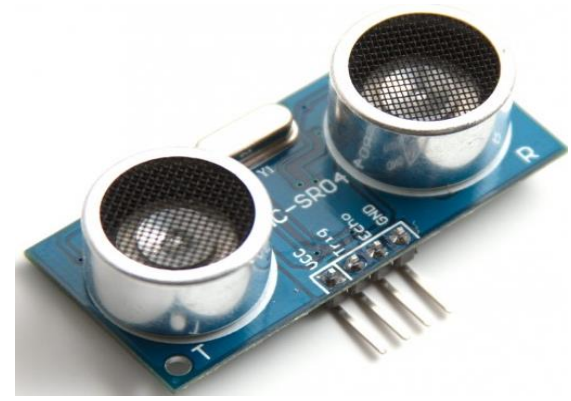

Fig. 2. Ultrasonic sensor HC-SR04

It should be noted that this sensor will help to detect the person, mention is made of this because it is the people who will approach the system and now of detecting them by distance, it will oversee correctly defining the distance the person should be.

\section{Sensor MLX90614}

The MLX90614 sensor, as seen in figure 3, is an infrared sensor that allows us to obtain a temperature reading of an object without contacting it. You can measure using in the temperature range of $-40{ }^{\circ} \mathrm{C}$ to $125^{\circ} \mathrm{C}$ in ambient temperatures and $-70^{\circ} \mathrm{C}$ to $380^{\circ} \mathrm{C}$ in objects. The sensor uses both emissivity and radiation to perform measurements [20]. Based on its characteristics, it is useful for the measurement system.

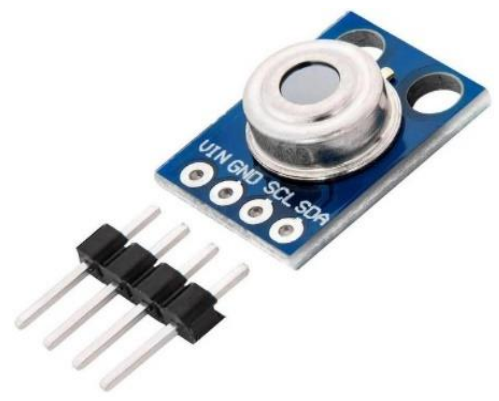

Fig. 3. Infrared sensor MLX90614

\section{Active buzzer}

The active buzzer, as can be seen in figure 4 , is a device that generates sound at a certain frequency and works with direct current from $4 \mathrm{v}$ to $8 \mathrm{v}$, in addition, this device has a resonance frequency of approximately $2300 \mathrm{~Hz}$ [21].

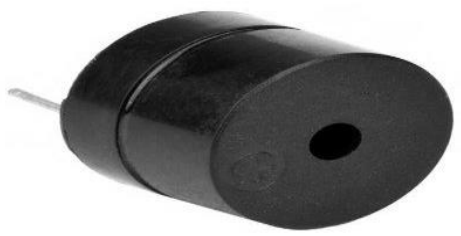

Fig. 4. Active buzzer

The buzzer will notify the personnel in charge of the system through the emission of a sound when the person is detected. Also, it will emit a sound when the person is correctly positioned in front of the system. Also, it will emit a sound when an elevated temperature is detected, all this will be done automatically.

\section{DETECCTION OF BODY TEMPERATURE}

For the detection of body temperature in people, the electronic components necessary for the system were analyzed to ensure its correct operation, it should be noted that said operation will be done automatically. 


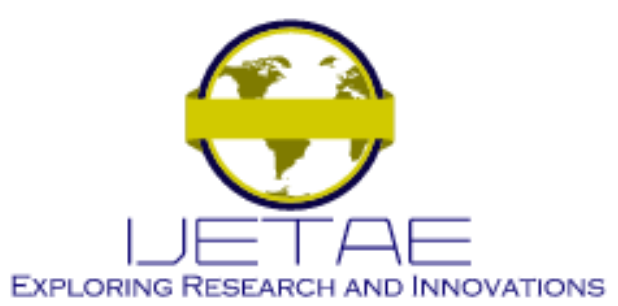

International Journal of Emerging Technology and Advanced Engineering

Website: www.ijetae.com (E-ISSN 2250-2459, Scopus Indexed, ISO 9001:2008 Certified Journal, Volume 12, Issue 02, February 2022)

The operation of the system is based on two stages, the first is the stage in which it will detect the person and place them at $50 \mathrm{~cm}$, the second is the stage where it will measure body temperature.

\section{A. First stage}

In this first stage, the measurement of the distance in which the person should be located will be conducted with the help of the ultrasonic sensor. It will have as an indicator the active buzzer that by means of a sound will indicate that the person is in the correct position. Figure 5 shows the way in which the first stage is conducted.

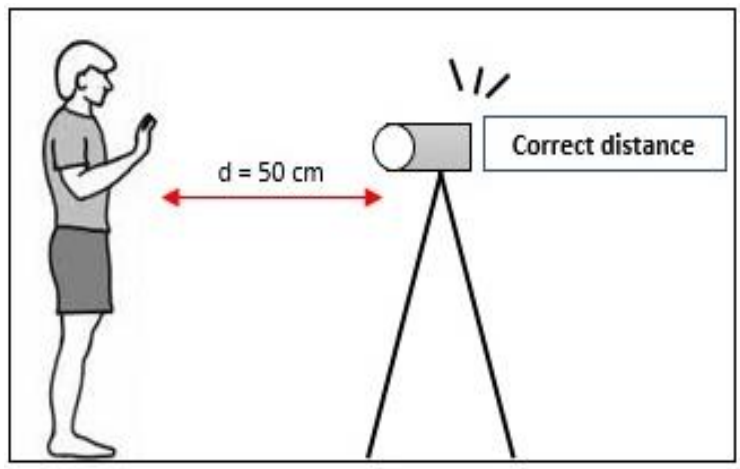

Fig. 5. Distance detector

\section{B. Second stage}

In the second stage, the body temperature will be measured; The measurement will be made on the part of the wrist because it is the part that is not covered by any garment and generally when a person makes some physical effort, the temperature in the hand is the one that is regulated faster than on the forehead, that is why that part of the body was chosen. On the other hand, being a temperature measurement system, it is intended to perform a quick and safe measurement, since there will be no physical contact between the person and the system.

At the time of body temperature measurement, the system will indicate a temperature value that will be normal if it is in the range of $35.1^{\circ} \mathrm{C}$ to $37.1^{\circ} \mathrm{C}$ and will give a warning by means of a green light, as well as it is observed in figure 6 .

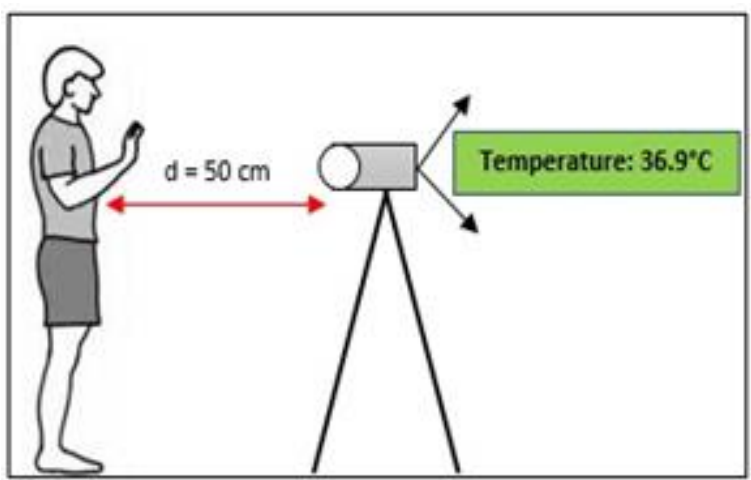

Fig. 6. Normal temperature measurement

If the system will indicate as elevated temperature if the value is higher than $37.1^{\circ} \mathrm{C}$ and will give a warning by means of a red light and will emit an alert sound, as shown in figure 7 .

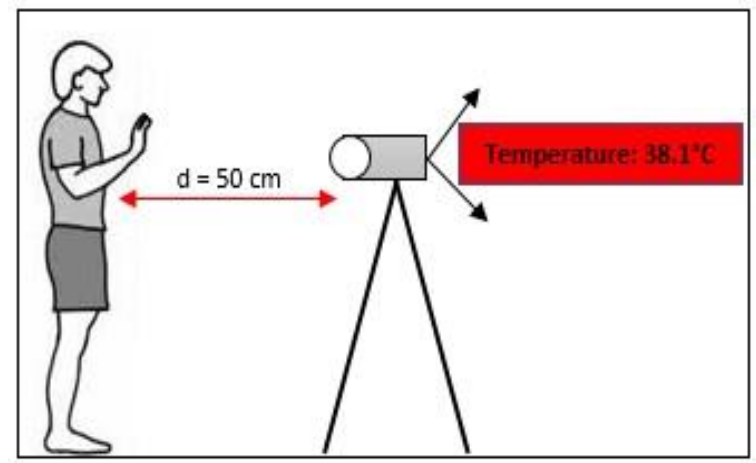

Fig. 7. High temperature measurement

\section{SYSTEM SIMULATION}

In this part, the simulation of the system was conducted, as can be seen in figure 8 , to see how its correct operation would be. Taking some measurements of the body temperature and seeing how the system shows it through an LCD screen each value obtained from said measurement. 


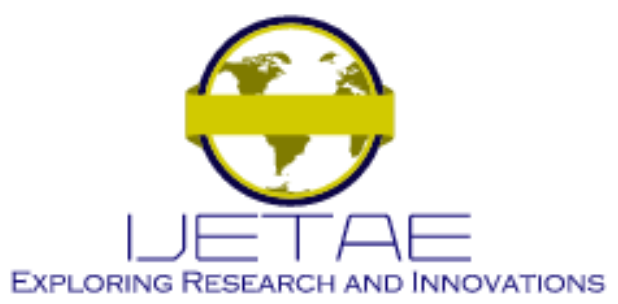

International Journal of Emerging Technology and Advanced Engineering

Website: www.ijetae.com (E-ISSN 2250-2459, Scopus Indexed, ISO 9001:2008 Certified Journal, Volume 12, Issue 02, February 2022)

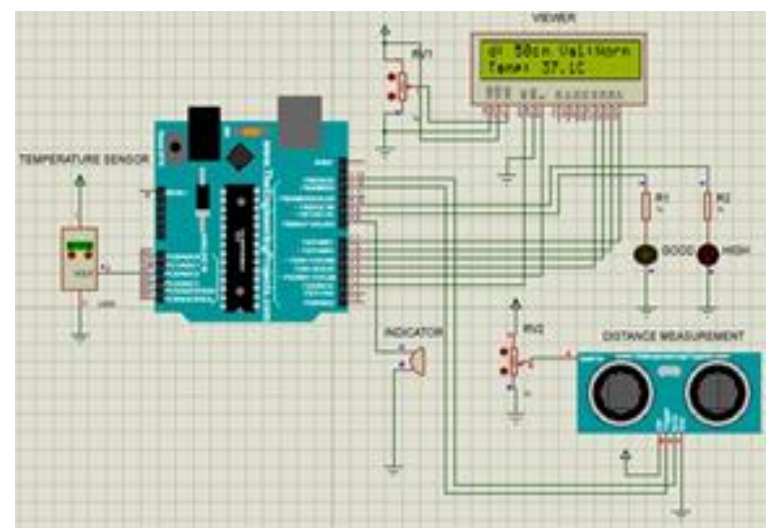

Fig. 8. System simulation

In this simulation, it is observed how the ultrasonic sensor calculated the value of $50 \mathrm{~cm}$, which is the distance in which the person must be in front of the body temperature sensor, once the person is at that distance, a sound will be emitted with the buzzer to indicate that it is in advantageous position. Then with the body temperature sensor, the measurement is made, and the system evaluates whether the temperature value is normal or high. If it is a normal temperature, it will give a warning with a green light, otherwise, being an elevated temperature, it will give a warning with a red light and it will emit an alert sound. For the manager to be able to view all the measurements made by the system, an LCD screen was used to make him aware. Furthermore, the tool used for the simulation of the system is the proteus software.

\section{RESULTS}

With the design of a body temperature measurement system applied to health center personnel, the objective of knowing the temperature of people when entering a health center would be fulfilled, in addition to being able to perform many measurements quickly to avoid crowds, and safe for everyone.

Table I indicates the characteristics of the body temperature measurement system. In accordance with the aforementioned, the system complies with each parameter that was indicated throughout the paper so that it performs its function correctly, being very useful to have knowledge about the body heat that each person may have, if in case it presents high body heat can cause fever and this is a common symptom of COVID-19, therefore, the system helps reduce transmission between people by quickly detecting this symptom.
TABLE I.

CHARACTERISTICS OF THE SYSTEM

\begin{tabular}{|c|c|}
\hline \multicolumn{2}{|c|}{ Body temperature measurement } \\
\hline Distance & $50 \mathrm{~cm}$ \\
\hline Temperature range & $\begin{array}{c}\text { Normal: } 35.1^{\circ} \mathrm{C} \mathrm{a} 37.1^{\circ} \mathrm{C} \\
\text { High: Greater than } 37.1^{\circ} \mathrm{C}\end{array}$ \\
\hline $\begin{array}{c}\text { Part where the } \\
\text { measurement is made }\end{array}$ & Wrist \\
\hline $\begin{array}{c}\text { System measurement } \\
\text { time }\end{array}$ & 8 seconds \\
\hline
\end{tabular}

By using the system, the body temperature of any person can be more accurately known, as can be seen in figure 9, showing that the measurement values are normal.

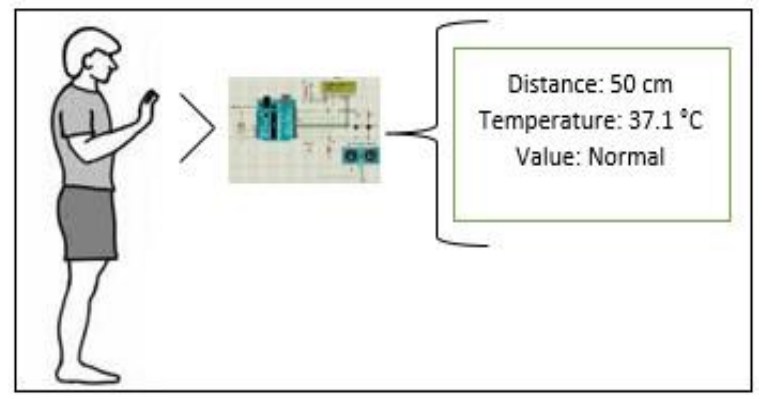

Fig. 9. Normal temperature

If the system detects a high temperature, it will display the measurement values and give a warning to take into account that the person may have a fever, as shown in figure 10 .

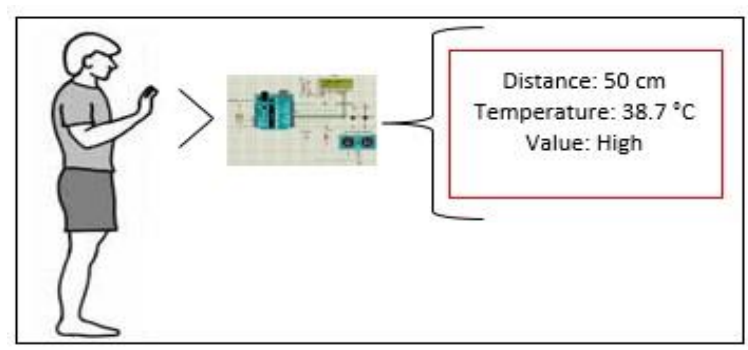

Fig. 10. High temperature

On the other hand, it should be noted that the ultrasonic sensor should not have obstacles, otherwise it will give another value of the distance. Once the person is accommodated, he must focus on the part of the wrist so that the system makes the corresponding measurement. 


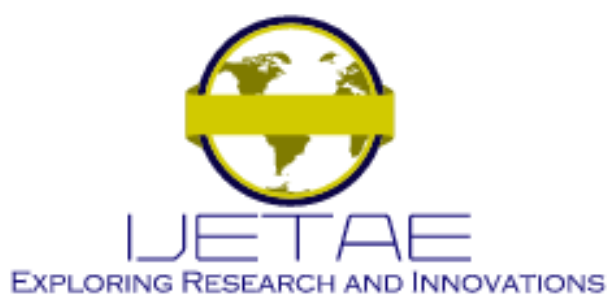

International Journal of Emerging Technology and Advanced Engineering Website: www.ijetae.com (E-ISSN 2250-2459, Scopus Indexed, ISO 9001:2008 Certified Journal, Volume 12, Issue 02, February 2022)

To develop the design of the measurement system, more commercial electronic devices were used in the market so that there are no inconveniences when wanting to implement it, although it is true, these devices are not expensive, but they have good efficiency in their development at the time of being used.

The development of the programming in the Arduino UNO board was conducted in such a way that the system fulfills its function correctly, this programming was developed in the Arduino IDE, being a crucial tool to be able to perform various functions.

\section{DISCUSSION}

Many researchers have conducted various research works to face COVID-19, because, being a new virus, they did not have the necessary tools to be able to combat it initially.

This research work fulfills its objective, with this, it would be helping to prevent the spread of the virus. On the other hand, this work presents some differences with other research works, for example, the work carried out by [13], where the author proposes to develop a system for measuring temperature and oxygen saturation levels for the monitoring of patients diagnosed with COVID -19 and its epidemiological fence. Where, they obtained a result of $96.45 \%$ efficiency, but this system was not evaluated with many people, it was simply developed and tested by the author. In addition, this system is complex when managing it.

We also have the work developed by [14], $d$ where the authors propose to develop the implantation of a thermographic device to identify body temperature in means of public transport in the MDQ. Where they obtained a result of $95.12 \%$ efficiency, but this system has a disadvantage because its result presents variations in relation to the distance and the height that is located, the ambient temperature and the height of the individual that is intended to be measured, for what this system is not dependable.

We also have the work developed by [15], where the authors propose to develop a wireless system for estimating mean body temperature. Where they obtained a result of $91.47 \%$ efficiency, but this system used a wireless module that has little range, on the other hand, its manipulation is complex so the system manager will take time to use it.

We also have the work developed by [16], where the authors propose to design and implement a roll call system with body temperature measurement and instant messaging software.
Where they obtained a result of $92.84 \%$ efficiency, but this system does not focus on the distance the person must be in front of the system so that their body temperature can be measured.

We also have the work developed by [17], where the authors propose to develop an automatic recording system for forehead temperature measurement. Where they obtained a result of $98.5 \%$, but this system does not specify that the data obtained from the measurement is exact, on the other hand, this system cannot be implemented in various places because it is expensive. Also, it is necessary for the person to have an RFID card, otherwise they will not be able to measure their body temperature.

We also have the work developed by [22], where the authors propose to develop an intelligent system for controlling the body temperature of children through mobile phones (a). This system has its own parameters that differ from this system (b), as shown in Table II.

TABLE II.

COMPARACIÓN ENTRE SISTEMAS

\begin{tabular}{|c|c|c|}
\hline Distance & $\mathrm{a}$ & $\mathrm{b}$ \\
\hline $\begin{array}{c}\text { Normal } \\
\text { temperature } \\
\text { range: }\end{array}$ & $\begin{array}{c}\text { Normal: } 36^{\circ} \mathrm{C} \text { a } 38^{\circ} \mathrm{C} \\
\mathrm{High}:>38^{\circ} \mathrm{C}\end{array}$ & $\begin{array}{c}\text { Normal: } 35.1^{\circ} \mathrm{C} \mathrm{a} \\
37.1^{\circ} \mathrm{C} \\
\text { High: }>37.1^{\circ} \mathrm{C}\end{array}$ \\
\hline $\begin{array}{c}\text { Measurement } \\
\text { site }\end{array}$ & Arm & Wrist \\
\hline $\begin{array}{c}\text { Measurement } \\
\text { time }\end{array}$ & 13 seconds & 8 seconds \\
\hline $\begin{array}{c}\text { System life } \\
\text { time }\end{array}$ & 5 months & 10 months \\
\hline Accuracy & $92.75 \%$ & $98.92 \%$ \\
\hline
\end{tabular}

\section{CONCLUSION}

It is concluded that the system works in the best way, makes correct and precise measurements, and determines if the person has a normal or elevated temperature. With this, you can help prevent people from getting COVID-19, since the system will give a warning if it detects an elevated temperature; Also, it is necessary to highlight that the system only requires 8 seconds to perform the measurement. 


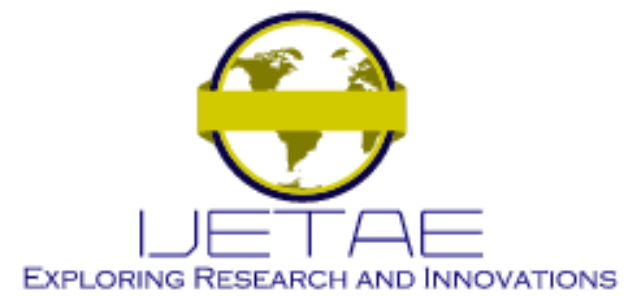

International Journal of Emerging Technology and Advanced Engineering Website: www.ijetae.com (E-ISSN 2250-2459, Scopus Indexed, ISO 9001:2008 Certified Journal, Volume 12, Issue 02, February 2022)

It is concluded that the system does not require any physical contact between the person and the person in charge, therefore, its manipulation by both parties is very safe since it only needs to see if the person who is being measured is okay, otherwise it should notify doctors to conduct the corresponding evaluations.

It is concluded that the system requires little time to perform the corresponding measurements, this is important since this will prevent people from crowding together waiting for the measurement to be conducted to enter the health center, with this, it will help with the order.

It is concluded that the system can be developed in various places, its operation will be in the best way. With this, the system would be of significant help because it would not present any limitation in its operation.

It is concluded that this system was developed to be able to combat COVID-19 that currently continues in our environment and continues to affect many people regardless of age, therefore, it is necessary to take the necessary precautions to avoid getting infected.

It is concluded that people who work in a health center must be protected and in good health, since they serve many people, otherwise they can generate a source of contagion.

An implementation of the system will be conducted as future work and it will be tested in several health centers, using the electronic components mentioned above so that it works in the best way.

It is recommended that this system can be implemented in all places and not only in closed places since it is necessary to combat this virus; Also, the ultrasonic sensor should not have obstacles for measurement.

\section{REFERENCES}

[1] M. Palacios Cruz, E. Santos, M. Velázquez Cervantes, and M. León Juárez, "COVID-19, a worldwide public health emergency," Rev. Clínica Española (English Ed., vol. 221, no. 1, pp. 55-61, Jan. 2021, doi: 10.1016/j.rceng.2020.03.001.

[2] P. M. Buss and S. Tobar, "La COVID-19 y las oportunidades de cooperación internacional en salud," Cad. Saude Publica, vol. 36, no. 4, pp. 1-3, Apr. 2020, doi: 10.1590/0102-311X00066920.

[3] D. Amsalem, L. Dixon, and Y. Neria, "The Coronavirus Disease 2019 (COVID-19) Outbreak and Mental Health: Current Risks and Recommended Actions," JAMA Psychiatry, vol. 78, no. 1, pp. 9-10, Jan. 2021, doi: 10.1001/jamapsychiatry.2020.1730.

[4] B. Morales Contreras and J. Palencia Sierra, "Reflexiones del cuidado enfermero en tiempos de COVID-19," Enfermería Investig., vol. 5, no. 3, pp. 71-78, Jul. 2020, doi: 10.31243/EI.UTA.V5I3.914.2020.
[5] E. Zevallos Santillan, J. Cruzado Burga, and R. Avalos Rivera, "COVID-19; Perú a los 100 días, breve observación de una pandemia que pone en serios aprietos a la salud pública mundial," Rev. Medica Hered., vol. 31, no. 4, pp. 287-289, Jan. 2020, doi: 10.20453/RMH.V31I4.3865.

[6] M. Adnan Shereen, S. Khan, A. Kazmi, N. Bashir, and R. Siddique, "COVID-19 infection: Emergence, transmission, and characteristics of human coronaviruses," J. Adv. Res., vol. 24, pp. 91-98, Jul. 2020, doi: 10.1016/j.jare.2020.03.005.

[7] U. Cáceres Bernaola, C. Becerra Núñez, S. Mendívil Tuchía de Tai, and J. Ravelo Hernández, "Primer fallecido por COVID-19 en el Perú," An. la Fac. Med., vol. 81, no. 2, pp. 201-204, Jul. 2020, doi: 10.15381/ANALES.V81I2.17858.

[8] G. Escobar, J. Matta, W. Taype, R. Ayala, and J. Amado, "Características Clinicoepidemiológicas de pacientes fallecidos por COVID-19 en un Hospital Nacional de Lima, Perú," Rev. la Fac. Med. Humana, vol. 20, no. 2, pp. 180-185, Mar. 2020, doi: 10.25176/RFMH.V20I2.2940.

[9] J. Gonzales Castillo, L. Varona Castillo, M. Domínguez Morante, and V. Ocaña Gutierrez, "Pandemia de la COVID-19 y las Políticas de Salud Pública en el Perú: marzo-mayo 2020,” Rev. Salud Pública, vol. 22, no. 2, pp. 1-9, Mar. 2020, doi: 10.15446/rsap.v22n2.87373.

[10] C. Maguiña Vargas, "Reflexiones sobre el COVID-19, el Colegio Médico del Perú y la Salud Pública," Acta Médica Peru., vol. 37, no. 1, pp. 8-10, Mar. 2020, doi: 10.35663/amp.2020.371.929.

[11] E. Villanueva, Fernámdez. M., E. Viano, and M. Amorín, "Fiabilidad en la medición de la temperatura corporal con un termómetro timpánico en pacientes geriátricos," SCIELO, vol. 28, no. 2 , pp. 68-72, Jun. 2020.

[12] A. Gervasini Navarro, "Diseño sistema de detección enfermos COVID," Universitat Politècnica de València, Valencia - España, 2021.

[13] S. Pineda Rosales, "Medidor de temperatura y saturación de niveles de oxígeno en sangre para la monitorización de pacientes diagnosticados por Covid-19 y su cerco epidemiológico, mediante el uso de algoritmos de aprendizaje de máquina, con el uso de aplicaciones del IOT," Universidad Técnica del Norte, Ibarra Ecuador, 2021.

[14] B. Silva Ramírez, D. Erazo Amaya, and G. Reyes-Campaña, "Implantación de dispositivo termográfico para identificar temperatura corporal en medios de transporte público del DMQ," Polo del Conoc., vol. 6, no. 6, pp. 56-80, Jun. 2021, doi: 10.23857/PC.V6I6.2742.

[15] L. Lopez, G. Dominguez, E. Cardiel, and P. Hernandez, "Wireless Measurement System for Mean Body Temperature Estimation," Pan Am. Heal. Care Exch. PAHCE, vol. 2019-March, pp. 1-6, May 2019, doi: 10.1109/GMEPE-PAHCE.2019.8717327.

[16] P. Y. Yen, Y. Y. Fanjiang, C. H. Hung, and T. M. Zhang, "Design and Implement a Roll Call System with Body Temperature Measurement and the Instant Messaging Software,” Dig. Tech. Pap. - IEEE Int. Conf. Consum. Electron., vol. 2021-January, pp. 1-2, Jan. 2021, doi: 10.1109/ICCE50685.2021.9427666.

[17] L. Sheng Hsiung and L. Ching Chun, "Automatic login system for forehead temperature measurement," Proc. - 2020 Int. Symp. Comput. Consum. Control. IS3C 2020, pp. 154-157, Nov. 2020, doi: 10.1109/IS3C50286.2020.00047. 


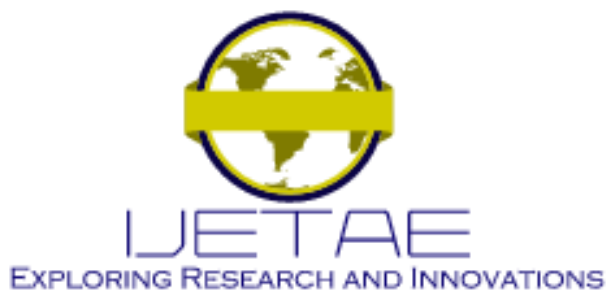

International Journal of Emerging Technology and Advanced Engineering

Website: www.ijetae.com (E-ISSN 2250-2459, Scopus Indexed, ISO 9001:2008 Certified Journal, Volume 12, Issue 02, February 2022)

[18] L. Nũnez Tapia, "A Prototype of an Automatic Irrigation System fo Peruvian Crop Fields," Int. J. Adv. Comput. Sci. Appl., vol. 11, no. 8, pp. 731-734, 2020, doi: 10.14569/IJACSA.2020.0110888.

[19] C. Blas, J. Alnaya, J. Figueroa, and M. Gutierrez, "Dispositivo automático de pulverización de alcohol para la desinfección de manos en prevención a la Covid-19," Ingenium, vol. 5, no. 1, Jun. 2020.

[20] K. Chicaiza Moncayo and G. Cordero Cerezo, "Desarrollo sistema web para monitoreo de temperatura corporal con dispensador automático gel antibacterial para prevenir contagios COVID-19 locales comerciales en Guayaquil mediante el uso de Arduino," Universidad de Guayaquil, Guayaquil - Ecuador, 2020.
[21] E. Escalante Orrala and L. Torres Pérez, "Diseño y elaboración de un prototipo de dispensador de líquidos para desinfección de inodoros con arduino y aplicación android," Universidad de Guayaquil. Facultad de Ciencias Matemáticas y Físicas. Carrera de Ingeniería en Networking y Telecomunicaciones, Guayaquil Ecuador, 2021.

[22] A. Anak, T. Huang, K. Kipli, K. Lee, and N. Sze, "Smart Body Temperature Monitoring system for Children via Mobile," 2018 Int. Conf. Comput. Approach Smart Syst. Des. Appl. ICASSDA 2018, pp. 1-6, Sep. 2018, doi: 10.1109/ICASSDA.2018.8477613. 